\title{
A Simple Method for Land Grading Computations and its Comparison with Genetic Algorithm (GA) Method
}

\author{
Hamid Raeisi-Vanani ${ }^{1}$, Mohammad Shayannejad ${ }^{2}$, Ali-Reza Soltani-Toudeshki ${ }^{3}$ \\ Mohammad-Ali Arab ${ }^{4}$, Saeid Eslamian ${ }^{5}$, Mahboubeh Amoushahi-Khouzani ${ }^{6}$ \\ Maryam Marani-Barzani ${ }^{7}$, Kaveh Ostad-Ali-Askari ${ }^{*}$ \\ 1,2,3,4,5 Department of Water Engineering, Isfahan University of Technology, Isfahan, Iran. \\ ${ }^{6}$ Water Engineering Department, Science and Research Branch, Islamic Azad University, \\ Tehran, Iran. \\ ${ }^{7}$ Department of Geography, University of Malaya (UM),50603 Kuala Lumpur, Malaysia. \\ ${ }^{8 *}$ Department of Civil Engineering, Isfahan (Khorasgan) Branch, Islamic Azad University, \\ Isfahan, Iran.
}

"Corresponding author: Kaveh Ostad-Ali-Askari, Department of Civil Engineering, Isfahan (Khorasgan) Branch, Islamic Azad University, Isfahan, Iran. Email: koa.askari@khuisf.ac.ir

\begin{abstract}
This paper reports the development of a new method for land grading computation having time saving and simplicity advantages. The conventional method uses the trial and error process to determine the desired cut-fill ratio, which is cumbersome and time-consuming. In developed method, the trial and error process is not necessary. Instead, the Excel Solver was applied to determine the plane equation of land grading, and minimize the earthwork volume based on a desirable cut-fill ratio. Then, results of the new method for three data sets were compared with the conventional and genetic algorithm (GA) methods. In all of the data sets, results of the new method were better than two other methods. The cut-to-fill ratio and cut volume were less in new method than others.
\end{abstract}

Keywords: Land leveling; Excel Solver; Plane equation; Cut-fill ratio; Minimum cut and fill volume.

\section{INTRODUCTION}

Land leveling or land forming is a form of soil disturbance that alters soil physical properties to facilitate more uniform distribution of irrigation water and is essential in improving the efficiency of surface irrigation as well as in removing excess water from the field surface [1]. Land leveling is very important in surface irrigation systems, because field surface is main transfer for water movement. Thus field surface forming should be so that water distribution has maximum uniformity [2]. Land leveling will become also more important in the future. The use of the leveling program by farmers and engineers to improve surface irrigation systems will increase productivity and water-use efficiency [3]. So Land leveling can be effective on yield. Johnson et al. (1978) showed that the average yield of the precision leveled fields is significantly more than the yield for traditional leveled. In addition, the mean time to irrigate a hectare field is significantly less for precision leveled than the traditional leveled [4]. The land leveling causes differences in soil depth and in soil layer characteristics along and across the plot. This helps to generate different soil moisture conditions at the same depth at different positions of the plot, so that the areas located at the top of the plot can shows soil moisture conditions in the surface layer that are up to 5\% lower than down slope. Also Leveled plots show a yield reduction in comparison with those undergoing less transformation [5]. The alteration of the soil profiles caused by land leveling significantly changed soil moisture at different depths and runoff rates at different slope positions., so that in low disturbed soils, low differences in soil moisture were observed, while in high disturbed soils, soil moisture and water infiltration of the surface were always lower than in the low disturbed ones, while soil sealing was higher in high disturbed than in the low disturbed soils. The most disturbed plot also showed a higher sediment concentration in runoff, which together with higher runoff volumes gave higher erosion rates and soil losses than the low disturbed one [6]. Irrigation application, distribution, and water-use efficiency are appreciably reduced with increase in leveling index $(1.2$ to $3.7 \mathrm{~cm})$ or deterioration in 
leveling quality. Yield is also similarly reduced and it is significantly less for leveling index values higher than $2.5 \mathrm{~cm}$. [7]. Irrespective of tillage and crop establishment methods, precision land leveling improves rice-wheat system productivity as compared to traditional land leveling. Total irrigation water savings under precision land leveling versus traditional land leveling can be $12-14 \%$ in rice and $10-13 \%$ in wheat. Precision land leveling improves rice-wheat system profitability by US $\$ 113 \mathrm{ha}^{-1}$ to $\$ 175 \mathrm{ha}^{-1}$ [8]. A precision land leveling is laser leveling. The introduction of laser leveling in the 1970 's produced a silent revolution that has raised potential of surface irrigation efficiency to the levels of sprinkler and drip irrigation [9]. The studies indicate significant increase in irrigation efficiencies of wheat and rice through precision leveling using laser land leveler [10]. Laser leveling is a process of smoothing the land surface $( \pm 2 \mathrm{~cm})$ from its average elevation using laser equipped drag buckets to achieve precision in land leveling. Precision land leveling involves altering the fields in such a way as to create a constant slope of 0 to $0.2 \%$. This practice makes use of large horsepower tractors and soil movers that are equipped with global positioning systems (GPS) and/or laser-guided instrumentation so that the soil can be moved either by cutting or filling to create the desired slope/level [11]. Land leveling cans also increase penetration resistance and results in a $0.1 \mathrm{~m}$ shallower hard pan, which effectively can be reduces the soil volume for subsequent crop root growth. Deep-tillage may be required following shallow-cut land leveling to help alleviate the poor soil physical condition [12]. Some factors that are necessary to consider in land leveling are consists of: land division to minimize soil displacement, field operations, other soil needs and conservation [13]. Plane method based on least squares is a usual way to land leveling computations that can be incorporated into computer programs to be used easily for all possible land leveling problems in fields with irregular boundaries [14]. The first accurate method for computing of land leveling cuts and fills based on least-squares theory was developed by Givan (1940). The least squares procedure leads to a system of three linear equations with three unknowns for determination of the best-fit plane. The equations can be solved by determinants (Cramer's rule) using a procedure capable of solution by many programmable calculators [15]. To determine best plane equation for minimizing cut and suitable cut-fill ratio, has been also written a program in FORTRAN and BASIC computer languages [16]. Simple formulas have been presented for direct land grading design that eliminates the need for trial and error procedures in land grading process. The formulas are based on the assumption that the before and after-grading volumes measured from a reference elevation are equal; the computed plane provides equal cut and fill volumes [17]. To reduce the cost of data collection can be used the threepoint method that allows the use of unequal intervals in land-grading grids [18]. A nonlinear optimization model based on genetic algorithms (GA) is developed for land grading design of irregular fields too. The model can be used to obtain of plane as well as curved surfaces [19]. Raju (1960) developed a method to calculate the slopes of the graded plane, which he called the fixedvolume center method. His method is based on minimizing of the cut and fill volumes and earth movement [20]. Land grading design by using nonlinear programming has been also developed and compared with those obtained from previously developed methods that results showed, this method is more efficient and very flexible in selecting a suitable graded surface for a given land. In this method has been used from a curve function for elevation of the graded surface at the points [21]. Linear programming was used for land grading design too [22]. Weighted average method has been used as well as for land grading design, that it is based on least-squares theory and does not have the cumbersome and time consuming calculations of the terms of the simultaneous equations that appear in the conventional least squares method. This method is amenable to both hand calculation and computer programming. Its suitability to hand calculation is an advantage. It can be used for both square grids and rectangular grids [23]. Biswal and Singh (1980) developed a general computer program for land grading using linear programming as a mathematical optimization technique for the depth of cut and fill, based on the simplex method [24].

Land grading computations are cumbersome and time-consuming by hand. The computations must be done by trial and error to achieve an optimal soil cut-fill ratio in order to determine the proper design plane. In this paper has been developed a quick method to achieve best cut-fill ratio and design plane for land grading. New method was also compared with conventional and GA methods.

\section{Methodology}

\subsection{Conventional Method}

In this paper was used from plane equation for land leveling. If field be with coordinates of $X-Y$, its plane equation is written as following: 
$E L(X, Y)=A X+B Y+C$

Where $E L(X, Y)=$ the elevation of a point with coordinates of $X$ and $Y ; A$ and $B=$ the regression coefficients (slope is both in $\mathrm{X}$ and $\mathrm{Y}$ directions); and $C=$ the elevation of the base coordinate. $A, B$ and $C$ values can be determined using following four steps in conventional method:

Step 1: Each point is related to an area, for example related area to point "a" is standard area $\left(A_{s}\right)$ and $\theta_{51} \cdot A_{S}$ is for point "b" in Fig.

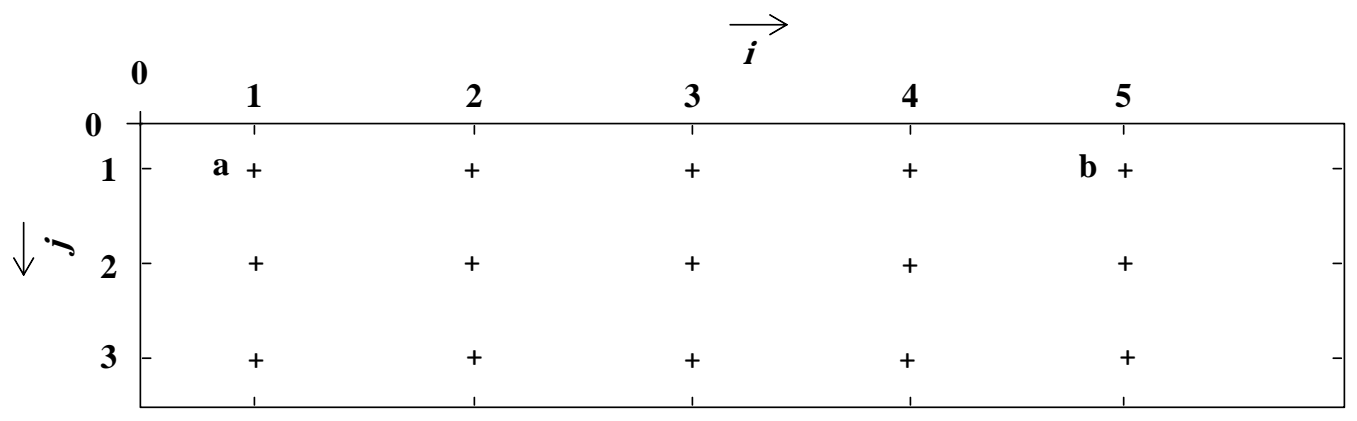

Fig 1. Field gridding and points in $i$ and $j$ rows

Therefore, for each point a weight factor is defined as following:

$\theta_{i j}=\frac{A_{i j}}{A_{s}}$

Where $\theta_{i j}=$ weight factor of $a_{i j}$ point; $A_{i j}=$ related area to $a_{i j}$. This is necessary to give different weights to related area to each point in the proximity of the field boundaries. Therefore, the actual cut and fill depths can be computed [25]. Interior regular grid points have a weighting factor of 1.00 .

Using of Eq. 2, average elevation in $i$ row, $E L_{i}$, is as Eq. 3:

$E L_{i}=\frac{\sum_{j=1}^{N^{\prime}} \theta_{i j} E L_{i j}}{\sum_{j=1}^{N^{\prime}} \theta_{i j}}$

Where $N^{\prime}=$ number of point in $\mathrm{Y}$ direction; $E L_{i j}=$ elevation of point $a_{i j}$.

Similar equation can be written for calculating of average elevation of $\mathrm{j}, E L_{j}$ as following:

$$
E L_{j}=\frac{\sum_{i=1}^{N^{\prime \prime}} \theta_{i j} E L_{i j}}{\sum_{i=1}^{N^{\prime \prime}} \theta_{i j}}
$$

Where $N^{\prime \prime}=$ number of rows in $X$ direction.

Step 2: Finding centroid location according to gridding system. Distance from point "O" to centroid in $X$ direction is calculated from Eq. 5:

$$
X=\frac{\sum_{j=1}^{N^{\prime}} \theta_{j} X_{j}}{\sum_{j=1}^{N^{\prime}} \theta_{j}}
$$


Where $X=$ distance from origin point to centroid; $X_{j}=X$ distance from origin point to $j$ row, and:

$\theta_{j}=\sum_{i=1}^{N^{\prime \prime}} \theta_{i j}$

Similarly,

$Y=\frac{\sum_{i=1}^{N "} \theta_{i} Y_{i}}{\sum_{i=1}^{N "} \theta_{i}}$

Where $Y=$ distance from origin point to centroid; $Y_{j}=Y$ distance from origin point to $i$ row, and:

$$
\theta_{i}=\sum_{j=1}^{N^{\prime}} \theta_{i j}
$$

Step 3: Calculation of least squares line [26] through the average elevations in both $X$ and $Y$ directions. Slope of best line in $X$ direction is $A$ that is determined by Eq. 9:

$$
A=\frac{\sum_{j=1}^{N^{\prime}} X_{j} E L_{j}-\left(\sum_{j=1}^{N^{\prime}} X_{j}\right)\left(\sum_{j=1}^{N^{\prime}} E L_{j}\right) / N^{\prime}}{\sum_{j=1}^{N^{\prime}} X_{j}^{2}-\left(\sum_{j=1}^{N^{\prime}} X_{j}\right)^{2} / N^{\prime}}
$$

The best slope in $Y$ direction is equal to Eq. 10:

$$
B=\frac{\sum_{i=1}^{N "} Y_{i} E L_{i}-\left(\sum_{i=1}^{N "} Y_{i}\right)\left(\sum_{i=1}^{N^{\prime \prime}} E L_{i}\right) / N^{\prime \prime}}{\sum_{i=1}^{N "} Y_{i}^{2}-\left(\sum_{i=1}^{N "} Y_{i}\right)^{2} / N^{\prime \prime}}
$$

Step 4: Calculation of $C$ value in Eq. 1. Average elevation in the field is $E L_{j}$ or $E L_{i}$ summation dividing to the rows number of gridding. This average elevation is elevation of field centroid $\left(E L_{F}\right)$. $X$ and $Y$ coordinates also are specified for center of gravity. So $C$ value is obtained from Eq. 11:

$$
C=E L_{F}-A X-B Y
$$

After determining of $A, B$ and $C$, plane equation will be specified. New elevation in each point was calculated using this equation. It is important to note that difference between primitive and new elevation is cut (negative values) or fill (positive values) height. $A$ and $B$ values should be in the acceptable range. For example, $A=0$ in border irrigation system. Four steps that were explained are based on minimizing soil displacement operations.

Cut and fill volume are calculated by Eq. 12 and 13 respectively:

$$
\begin{gathered}
V_{c}=\sum_{m=1}^{N_{c}} A_{m} C_{m} \\
V_{f}=\sum_{n=1}^{N_{f}} A_{n} F_{n}
\end{gathered}
$$

Where $V_{c}=$ cut volume, $m^{3} ; V_{f}=$ fill volume, $m^{3} ; A_{m}, A_{n}=$ related area to point " $m$ " and " $n$ " respectively, $m^{2} ; C_{m}=$ cut depth in point “ $m$ ", $m^{2} ; F_{n}=$ fill depth in point " $n$ ”, $m^{2}$. 
Ratio of Cut to fill volumes, $R$, is as following:

$$
R=\frac{V_{c}}{V_{f}}
$$

$R$ value should be in range of 1.1 to 1.5 [27]. $R$ depends on type of soil and the operating conditions during land grading [28].

\subsection{New Method}

New method for leveling is the purpose of presented paper that is to be minimize of $f\left(V_{c}, V_{f}\right)$ in Eq. 15 and $R=1.1-1.5$.

$$
f\left(V_{c}, V_{f}\right)=V_{c}+V_{f}
$$

Thus $R=1.1$ (or any arbitrary value according to soil type and leveling operation) and minimizing of $f\left(V_{c}, V_{f}\right)$ and $V_{c}$ are objective functions. One of software for optimization and reaching to purpose functions is Solver Excel. For achieving to the paper purposes, leveling plane equation was calculated with using Solver software in Excel. An example using of Solver software for attaining to these objectives is showed in Fig.

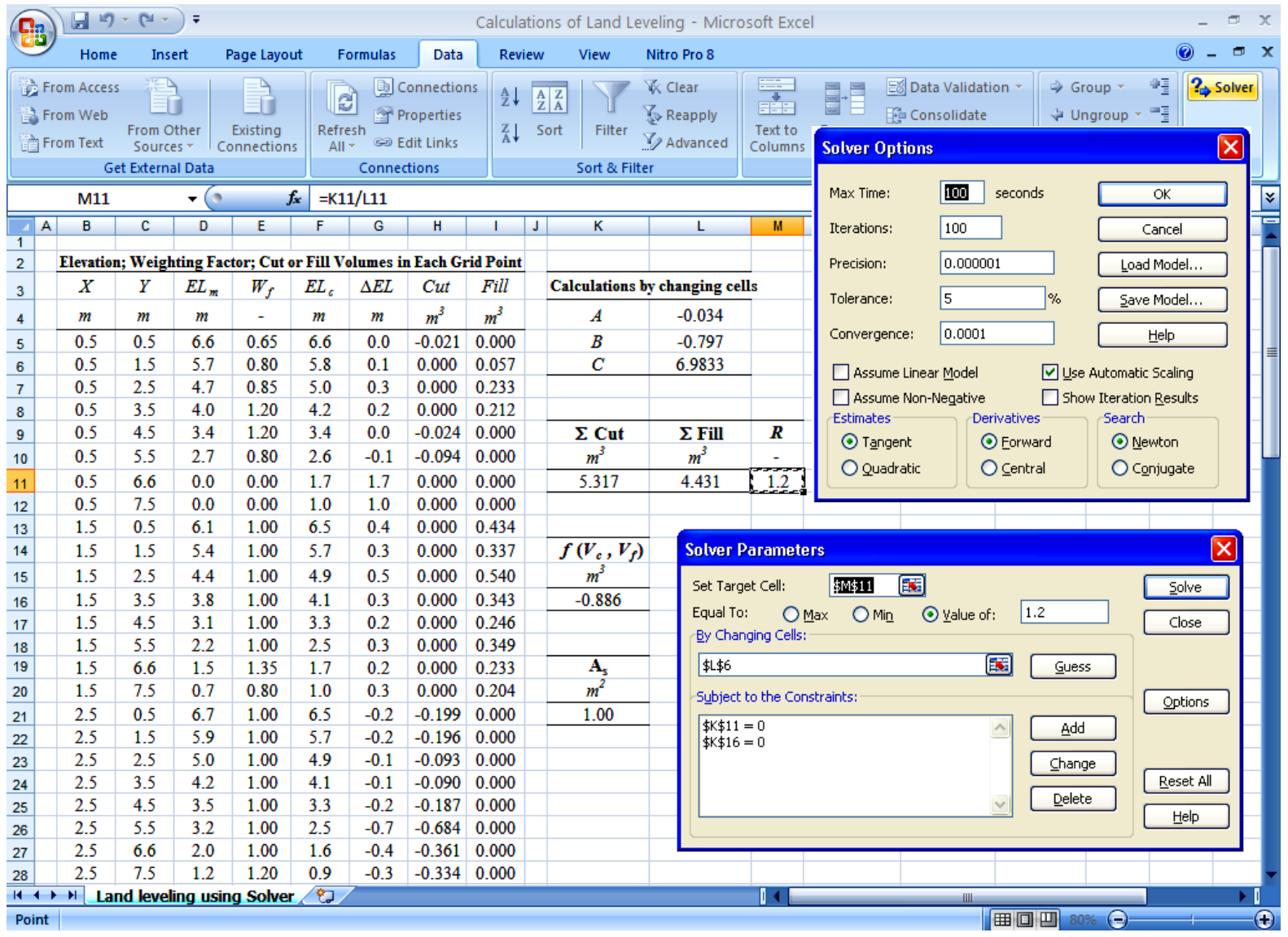

Fig 2. Example of leveling plane equation calculated by Solver software in Excel

For minimizing of $V_{c}$ and $f\left(V_{c}, V_{f}\right)$ in "subject to the constraints" box were applied $V_{c}=0$ and $f\left(V_{c}, V_{f}\right)=0$.

In Fig, desired $R$ is $1.2, W_{f}=$ Weighting Factor and $\Delta E L$ is cut or fill height that $\Delta E L=E L_{c}-E L_{m}$. Where $E L_{c}=$ new elevation of points on leveling plane equation and $E L_{m}=$ primitive elevation that was measured by surveying. It is important to say that negative slopes are downhill. In "Solver options" tab was used from "Use Automatic Scaling" according to Fig. Initial 
values of $A, B$ and $C$ were determined according to slope and field shape constraints for gravity irrigation. Program was run by clicking of Solve key and optimal $A, B$ and $C$ values were obtained according to constraints. To determine of cut and fill volumes was used from IF function in Excel, so that functions of IF ( $\Delta E L>0 ; \Delta E L ; 0)$ and $\operatorname{IF}(\Delta E L<0 ; \Delta E L ; 0)$ were applied for calculation of fill and cut volumes respectively. $A_{m}, A_{n}$ were also used for determination of cut and fill volumes. $A_{m}, A_{n}$ were obtained by standard area and weight factor in the gridding. ABS function was only used in calculation of cut volume not in $f\left(V_{c}, V_{f}\right), V_{c}$ and $V_{f}$ calculations.

\subsection{Genetic Algorithm Method}

GA is based on Darwin's theory of survival of the fittest for optimal search techniques [29-33]. GA is different than more traditional nonlinear and linear optimization procedures. GA will be working with a group of most-fit decision vectors. In contrast, the more traditional nonlinear and linear optimization procedures work with only one decision vector at any given time [34-49]. GA uses a wide variety of parameters as decision variables. These differences make the genetic algorithms more robust for nonlinear and linear optimization problems such as land grading, over their more traditional counterparts. As GA works with an unconstrained objective function, the constrained optimization problem is converted into an unconstrained one, using exterior penalty functions [50-63].

In this paper GA method was used as following:

If $E_{i j}$ is the elevation of the natural surface, vertical distance $D_{i j}$ between the natural and the graded surface may be computed using $D_{i j}$ :

$$
\begin{aligned}
& D_{i j}=E_{i j}-Z_{i j} \\
& Z_{i j}=C_{1}+C_{2} x_{i j}^{m}+C_{3} y_{i j}^{n}
\end{aligned}
$$

Where $C_{1}=$ elevation of graded surface at origin of coordinate axis; $C_{2}$ and $C_{3}$ are coefficients; and $m$ and $n$ are exponents. Exponents of $m$ and $n$ are 1.00 in linear optimization procedures.

The aim of any optimal land grading design should be to minimize the total volume of earth in cut while satisfying certain design constraints. In the proposed study, the optimal land grading design problem is formulated mathematically as a nonlinear programming problem subject to both linear and nonlinear constraints. The objective of the present optimization model is to minimize the volume of earth in cut. Mathematically, this may be written as:

minimize $V_{c}\left(C_{1}, C_{1}, C_{1}, m, n\right)$

Where $V_{c}=$ volume of earth in cut, which is a nonlinear function described in Eq. 17. For all of field the objective function may now be written as:

minimize $V_{c}=\sum_{i=1}^{N X} \sum_{j=1}^{N Y} D_{i j} A_{i j} K_{i j} ; K_{i j}=1$ for $D_{i j}>0, K_{i j}=0$ for $D_{i j}<0$

Where $A_{i j}=$ area represented by grid point $(i, j) ; K_{i j}=$ multiplication factor; and $N X$ and $N Y=$ number of grid points in the $X$ - and $Y$-directions, respectively.

Optimization to minimize the objective function needs to be carried out subject to the following design constraints:

$$
\begin{aligned}
& L_{C_{1}} \leq C_{1} \leq U_{C_{1}} \\
& D_{i j} \leq U_{D} \\
& S X_{i j}=\frac{\partial Z_{i j}}{\partial x_{i j}}=C_{2} m x_{i j}^{m-1} ; j=1,2, \ldots N Y \quad L_{S X_{i j}} \leq S X_{i j} \leq U_{S X_{i j}} \\
& S Y_{i j}=\frac{\partial Z_{i j}}{\partial y_{i j}}=C_{3} n y_{i j}^{n-1} ; j=1,2, \ldots N X \quad L_{S Y_{i j}} \leq S Y_{i j} \leq U_{S Y_{i j}} \\
& L_{R} \leq R \leq U_{R}
\end{aligned}
$$


Where $S X_{i j}$ and $S Y_{i j}$ are slope in the $X$ and $Y$ direction respectively, $R=$ cut-to-fill ratio that is in specified range. In Eq. 20-24 $L$ represents the lower bound and $U$ represents the upper bound. Lower and upper bounds were determined based on gravity flow of water for irrigation, avoiding excessive loss of top productive soil for irrigation, facilitating the gravity flow of water for irrigation or to prevent soil erosion in the case of land drainage, soil type and land grading operation [64-66].

In the present model, a search technique based on GA is used to solve the optimal design problem, as it is most suited for problems of this kind.

In this study was applied MATLAB software for doing GA process.

\section{Application}

In this research a field with the width of $13 \mathrm{~m}$ and the length of $110 \mathrm{~m}$ was selected for land leveling. Soil compaction was resolved with plowing and disking and then initial leveling was done by traditional leveler. Field boundaries were marked and a bench mark point was considered to convert readings in surveying to elevation and then field was surveyed and gridded for leveling operation (Fig, 4 and 5).
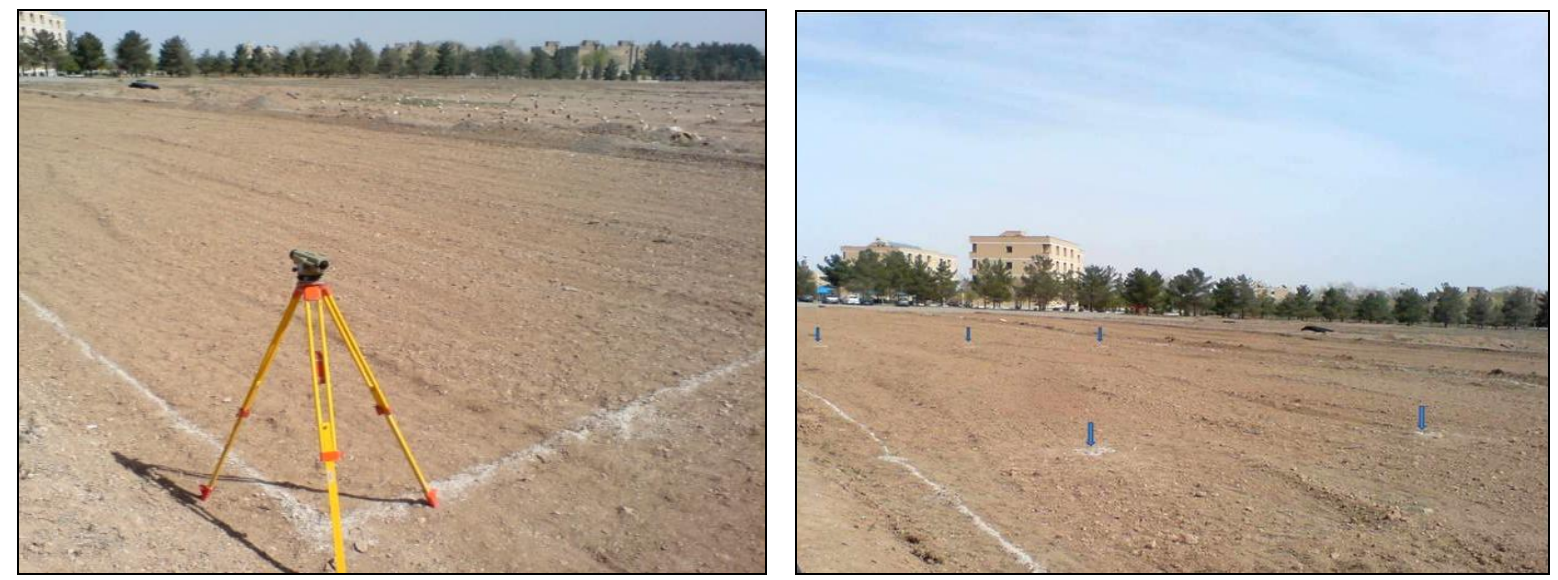

Fig 3. Field boundaries; Field surveying and gridding after initial leveling

\begin{tabular}{|c|c|c|c|c|c|c|}
\hline \multirow{2}{*}{0} & \multicolumn{5}{|c|}{$Y$-axis $(m)$} & \multirow[b]{2}{*}{110} \\
\hline & 10 & 30 & 50 & 70 & 90 & \\
\hline 2.2 & $\begin{array}{r}1 \\
+\quad 0.57\end{array}$ & $\begin{array}{l}1 \\
+\quad 0.57\end{array}$ & $\begin{array}{r}0.55 \\
+\end{array}$ & $\begin{array}{r}+ \\
+\quad 0.50\end{array}$ & +0.33 & Elevation at Grid \\
\hline & 1.00 & 1.00 & 1.00 & 1.00 & 1.50 & point \\
\hline 䑻 6.5 - & $+\begin{array}{r}0.60 \\
1.00\end{array}$ & $+\begin{array}{r}0.51 \\
1.00\end{array}$ & $+\begin{array}{l}0.41 \\
1.00\end{array}$ & $\begin{array}{r}0.35 \\
1.00\end{array}$ & $+\begin{array}{l}0.23< \\
1.50<\end{array}$ & $\begin{array}{c}\text { Area Weighting } \\
\text { Factor }\end{array}$ \\
\hline 10.8 & $\begin{array}{r}0.50 \\
+1.00\end{array}$ & $\begin{array}{r}0.49 \\
1.00\end{array}$ & $\begin{array}{r}0.42 \\
1.00\end{array}$ & $\begin{array}{r}0.38 \\
1.00\end{array}$ & $\begin{array}{r}0.24 \\
1.50\end{array}$ & \\
\hline
\end{tabular}

Fig 4. Elevation (meter) and area weighting factor at each grid point (first data set)

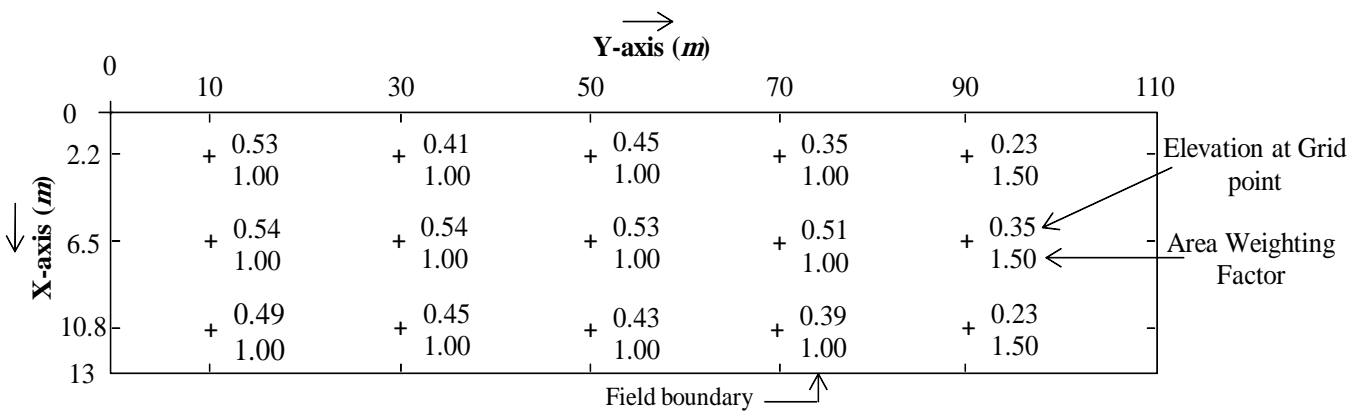

Fig 5. Elevation (meter) and area weighting factor at each grid point (second data set)

Topography and elevation of each point was determined and common, GA and new methods were used for leveling calculations and then were compared together. Leveling plane equations determined with usual, GA and new methods are presented as Eqs. 25, 26 and 27 for first data set respectively: 


$$
\begin{aligned}
& E L(X, Y)=-0.0112 X-0.0035 Y+0.684 \\
& E L(X, Y)=-0.0140 X-0.0040 Y+0.764 \\
& E L(X, Y)=-0.0104 X-0.0039 Y+0.701
\end{aligned}
$$

Similarly, for second data set equations were written as following:

$$
\begin{aligned}
& E L(X, Y)=+0.0004 X-0.0028 Y+0.556 \\
& E L(X, Y)=+0.0040 X-0.0020 Y+0.486 \\
& E L(X, Y)=+0.0018 X-0.0029 Y+0.555
\end{aligned}
$$

In first and second data sets desired $R$ is 1.1 and $A_{s}=20 \times 4.3 \mathrm{~m}^{2}$.

Third data set was used from Reddy (1996). This data are shown in Fig:

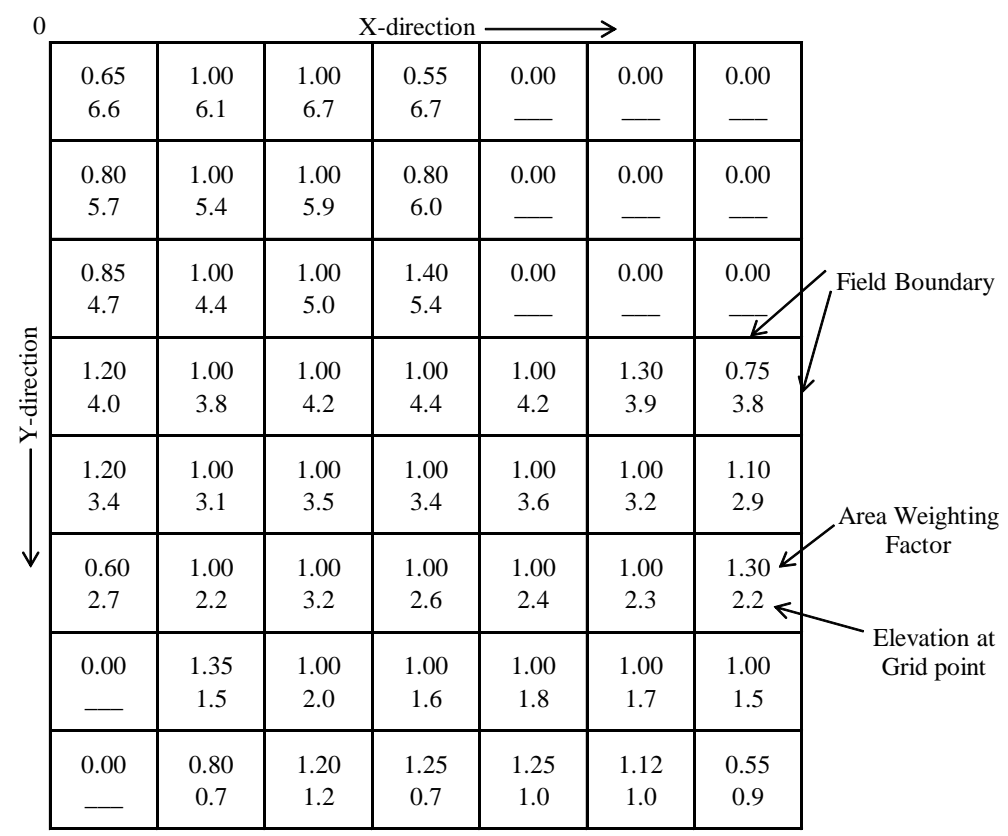

Fig 6. Land gridding; area weighting factor; and elevation (third data set) at grid point (Reported by Reddy, 1996)

Area of each square is $1.00 \mathrm{~m}^{2}$ in Fig, thus, $A_{s}=1.00 \mathrm{~m}^{2}$ and desired $R=1.2$. Obtained equations for leveling plane using usual, GA and the new methods are as following equations respectively:

$$
\begin{aligned}
& E L(X, Y)=-0.0105 X-0.7976 Y+7.3094 \\
& E L(X, Y)=-0.0270 X-0.8140 Y+7.4472 \\
& E L(X, Y)=-0.0335 X-0.7970 Y+6.9833
\end{aligned}
$$

\begin{tabular}{|c|c|c|c|c|c|c|c|c|c|c|}
\hline \multirow[b]{2}{*}{ Parameters } & \multirow[b]{2}{*}{ Unit } & \multicolumn{3}{|c|}{ First data set } & \multicolumn{3}{|c|}{ Second data set } & \multicolumn{3}{|c|}{ Third data set } \\
\hline & & Conv method & GA method & New method & Conv method & GA method & New method & Conv method & GA method & New method \\
\hline$V_{c}$ & $m^{3}$ & 26.904 & 30.267 & 23.936 & 38.396 & 40.780 & 37.477 & 5.359 & 5.346 & 5.317 \\
\hline$V_{f}$ & $m^{3}$ & 23.746 & 27.516 & 21.760 & 34.082 & 37.072 & 34.070 & 4.466 & 4.455 & 4.431 \\
\hline$R$ & $m^{3} / m^{3}$ & 1.133 & 1.100 & 1.100 & 1.127 & 1.100 & 1.100 & 1.200 & 1.200 & 1.200 \\
\hline$S_{x}$ & $m / m$ & -0.0112 & -0.0140 & -0.0104 & 0.0004 & 0.0040 & 0.0018 & -0.0105 & -0.0270 & -0.0335 \\
\hline$S_{y}$ & $m / m$ & -0.0035 & -0.0040 & -0.0039 & -0.0028 & -0.0020 & -0.0029 & -0.7976 & -0.8140 & -0.7970 \\
\hline
\end{tabular}

For better comparison of three methods and $R, V_{c}, V_{f}$ values in three data sets, Table 1 has been presented:

Table 1. Comparison of three methods for land grading with three data sets

Note: Conv = Conventional; desired $R$ in first and second data sets is 1.1 and in third data set is $1.2 ; S_{x}=$ slope in $X$-direction; $S_{y}=$ slope in $Y$-direction. 
It is important to note that to achieve to the desired $R$ in conventional method was used from trial and error method, because $R$ value was undesired in initial steps. For this work if $R$ value to be too high, the leveling plane should be raised and if $R$ value to be too small, the plane should be lowered by parallel shifting of initial plane and cut and fill volumes should be recalculated. So application of the conventional method is very complicated and time-consuming. With comparing of the three methods was found that new method has minimum cut and fill and is quicker than the other methods to determine optimal $R$. Table 1 shows that in the new method, cut volume is less than other methods and this is desirable, because of cut operations is expensive. This subject is one of the advantages of the new method. In the new method is not necessary to be done the previous four steps that were explained in conventional method. Best plane equation was calculated using the new method in the first stage even in fields with irregular boundaries and is not necessary to trial-and-error process. The centroid location and its elevation are not required also in the computational process in the new method in contrast of conventional method. According to Table 1 new method in first and second data sets implies better irrigation efficiency in the $Y$-direction (advance direction) due to more $B$ value and less erosion in the $X$-direction due to less $A$ value that are very important objects in irrigation system design. In third data set better irrigation efficiency and less erosion there are in $X$ - and $Y$ directions respectively in the new method. Also due to less top productive soil movement in the field, the new method could be important in sustainable development and agricultural operation that this subject shows itself more in the larger field. It should be noted that $R$ greater than 1.00 is necessary, because of the soil compaction in fill parts by leveling machine and visual errors that can increase fill volume [67-73].

With comparison of new and GA methods (as optimal land grading method) was found that new method gives a better plane equation than GA in terms of cut volume and field slope.

Finally, the grade elevation at the farm turnout was checked to make sure that it allows gravity irrigation from the water source according to $C$ value.

\section{Conclusion}

Because leveling is expensive and high soil displacement makes no surface fertile soil in some parts of the field, method with minimum soil displacement is common method of leveling operations in agricultural land. In this paper, to achieve these objectives were used three data sets and leveling plane equation was determined through minimizing cut and fill operations by Excel Solver as new method. Results showed that this method as compared to the conventional method, which is consists of four steps to determine of leveling plane equation, and GA method, as optimal land grading method, provides a high better plane equation in terms of cut volume and field slope and it is also a quicker method.

\section{REFERENCES}

[1] Agarwal, M. C. and A. C. Goel. 1981. Effect of field leveling quality on irrigation efficiency and crop yield. Agr. Water Manage. 4: 457-464.

[2] Anderson, C. L., A. D. Halderman, H. A. Paul, and E. Rapp. 1980. Land shaping requirements. Design and operation of farm irrigation systems. ASAE Monogr. 3, St. Joseph, Mich., Chap. 8.

[3] Biswal R. N. and G. Singh. 1980. A general computer program for land grading using linear programming. Agr. Syst. 5: 19-27.

[4] Brye, K. R., N. A. Slaton and R. J. Norman. 2005. Penetration resistance as affected by shallowcut land leveling and cropping. Soil till. Res. 81: 1-13.

[5] Ebne-Jalal, R. 2004. Weighted average method for land grading design. J. Irrig. Drain Eng. ASCE. 130 (3): 239-247.

[6] Erie, L. J. and Dedrick, A. R. 1979. Level basin irrigation: A method for conserving water and labor. USDA Farmers' Bulletin 2261, 23.

[7] Easa, S. M. 1989. Direct land grading design of irrigation plane surfaces. J. Irrig. Drain Eng. ASCE. 115 (2): 285-301.

[8] Easa, S. M. 1989. Three-point method for estimating cut and fill volumes of land grading. $J$. Irrig. Drain Eng. ASCE. 115 (3): 505-511.

[9] Gebre-Selassie N. A. and L. S. Willardson. 1991. Application of least-squares land leveling. J. 
Irrig. Drain Eng. ASCE. 117: 962-966.

[10] Givan, G. E. 1940. Land grading calculations. Agric. Eng. 21 (1): 11-12.

[11] Goldberg, D. E. 1989. Genetic algorithms in search, optimization and machine learning. Addison-Wesley Publishing Co., Reading, Mass.

[12] Hamad, S. N. and A. M. Ali. 1990. Land-grading design by using nonlinear programming. $J$. Irrig. Drain Eng. ASCE. 116 (2): 219-226.

[13] Hart, W. E. 1975. Irrigation system design. Department of agricultural and chemical engineering, Colorado state university, Fort Collins, Colo.

[14] Jat. M. L., M. K. Gathala, J. K. Ladha, Y. S. Saharawat, A. S. Jat, V. Kumar, S. K. Sharma, V. Kumar, R. Gupta. 2009. Evaluation of precision land leveling and double zero-till systems in the rice-wheat rotation: Water use, productivity, profitability and soil physical properties. Soil till. Res. 105: 112-121.

[15] Johnson, S. H., Z. S. Khan and C. M. Husain. 1978. The economics of precision land leveling: A case study from Pakistan. Agr Water. Manage. 1: 319-331.

[16] Lin, C. Y., and P. Hazela. 1992. Genetic algorithms in optimization problems with discrete and integer design variables. Engrg. Optimization. 19 (3): 309-327.

[17] Marr, J. C. 1967. Grading land for surface irrigation. Circ. 408. California agricultural experiment station, University of California, Davis, Calif.

[18] Rajput, T. B. S. and Patel, N. 2004. Effect of land leveling on irrigation efficiencies and wheat yield. J. Soil Water. Conserv. 3 (1\&2): 86-96.

[19] Raju, V. S. 1960. Land grading for irrigation. Trans. ASAE. 3 (1): 38-41.

[20] Ramos, M. C. and J. A. Martinez-Casasnovas. 2006. Impact of land leveling on soil moisture and runoff variability in vineyards under different rainfall distributions in a Mediterranean climate and its influence on crop productivity. J. Hydrol. 321: 131-146.

[21] Ramos, M. C. and J. A. Martinez-Casasnovas. 2007. Soil loss and soil water content affected by land leveling in Penedes vineyards, NE Spain. Catena. 71: 210-217.

[22] Reddy, L. S., and K. Elango. 1992. Optimal design of water distribution networks with headdependent outflows using Augmented Lagrangian functions. J. Inst. of Engrs. (INDIA)-Envir. Engrg. Div. 73 (2): 27-33.

[23] Reddy, S. L. 1996. Optimal land grading based on genetic algorithms. J. Irrig. Drain Eng. ASCE. 122 (4): 183-188.

[24] Scaloppi, E. J. and L. S. Willardson. 1986. Practical land grading based on least squares. J. Irrig. Drain Eng. ASCE. 112 (2): 98-109.

[25] Sowell, R., S. Shih and G. Kriz. 1973. Land forming design by linear programming. Trans. ASAE. 16 (3): 296-301.

[26] U. S. Department of Agriculture, Soil conservation service. 1970. Land leveling, National engineering handbook, U. S. Government printing office. Washington, D. C., chap. 12.

[27] Walker, T. W., W. L. Kingery, J. E. Street, M. S. Lox, J. L. Oldham, P. D. Gerard and F. X. Han. 2003. Rice yield and soil chemical properties as affected by precision land leveling in alluvial soils. Agron. J. 95: 1483-1488.

[28] Walker, W. R., and Skogerboe, G. V. (1987). Surface irrigation: Theory and Practice. PrenticeHall, Englewood Cliffs, New Jersey. 386p.

[29] Walker, W. R. 1989. Guidelines for designing and evaluating surface irrigation systems. FAO, Irri. Drain. paper 45.

[30] Zissis, T. S., A. H. Papadopoulos and I. S. Teloglou. 1996. Weighted factors in computer-aided land leveling. J. Irrig. Drain Eng. ASCE. 122: 336-338.

[31] Ostad-Ali-Askari, K., Shayannejad, M. 2015, Study of sensitivity of Autumnal wheat to under irrigation in Shahrekord, Shahrekord City, Iran. International Journal of Agriculture and Crop Sciences, 8 (4), 602-605.

[32] Shayannejad, M., Akbari, N., Ostad-Ali-Askari, K. 2015, Study of modifications of the river physical specifications on muskingum coefficients, through employment of genetic algorithm. International Journal of Development Research, 5(3), 3782-3785. 
[33] Ostad-Ali-Askari, K., Shayannejad, M. 2015, The Reviews of Einstein's Equation of Logarithmic Distribution Platform and the Process of Changes in the Speed Range of the Karkheh River, Khuzestan province, Iran. International Journal of Development Research, 5(3), 3786-3790.

[34] Ostad-Ali-Askari, K., Shayannejad, M., Ghorbanizadee - Kharazi, H. 2015, Assessment of artificial neural network performance and exponential regression in prediction of effective rainfall, International Journal of Development Research, 5(3), 3791-3794.

[35] Shayannejad, M. Akbari, N. and Ostad-Ali-Askari, K. 2015, Determination of the nonlinear Muskingum model coefficients using genetic algorithm and numerical solution of the continuity. Int. J. of Science: Basic and Applied Research, 21(1),1-14.

[36] Ostad-Ali-Askari, K., Shayannejad, M. 2015, The Study of Mixture Design for Foam Bitumen and the Polymeric and Oil Materials Function in Loose Soils Consolidation. Journal of Civil Engineering Research, 5(2), 39-44. DOI: 10.5923/j.jce.20150502.04

[37] Sayedipour, M., Ostad-Ali-Askari, K., Shayannejad, M. 2015, Recovery of Run off of the Sewage Refinery, a Factor for Balancing the Isfahan-Borkhar Plain Water Table in Drought Crisis Situation in Isfahan Province-Iran. American Journal of Environmental Engineering, 5(2): 43-46. DOI: 10.5923/j.ajee.20150502.02

[38] Ostad-Ali-Askari, K., Shayannejad, M. 2015, Developing an Optimal Design Model of Furrow Irrigation Based on the Minimum Cost and Maximum Irrigation Efficiency. International Bulletin of Water Resources \& Development, 3(2), 18-23.

[39] Ostad-Ali-Askari, K., Shayannejad, M. 2015, Presenting a Mathematical Model for Estimating the Deep Percolation Due to Irrigation. International Journal of Hydraulic Engineering, 4(1), 17 21. DOI: 10.5923/j.ijhe.20150401.03.

[40] Ostad-Ali-Askari, K., Shayannejad, M. 2015, Usage of rockfill dams in the HEC-RAS software for the purpose of controlling floods. American Journal of Fluid Dynamics, 5(1), 23-29. DOI: 10.5923/j.ajfd.20150501.03.

[41] Raeisi-Vanani, H., Soltani Todeshki, A. R., Ostad-Ali- Askari, K., Shayannejad, M. 2015, The effect of heterogeneity due to inappropriate tillage on water advance and recession in furrow irrigation. Journal of Agricultural Science, 7(6), 127-136.

[42] Soltani-Todeshki, A. R., Raeisi-Vanani, H., Shayannejad, M., Ostad-Ali-Askari, K. 2015, Effects of magnetized municipal effluent on some chemical properties of soil in furrow irrigation. International Journal of Agriculture and Crop Sciences, 8(3), 482-489.

[43] Ostad-Ali-Askari, K., Shayannejad, M. 2015, Optimal design of pressurized irrigation laterals installed on sloping land. International Journal of Agriculture and Crop Sciences, ISSN 2227670X. 8(5), 792-797.

[44] Ostad-Ali-Askari K, Shayannejad M, Eslamian S, Navab-Pour B. 2016, Comparison of solution of Saint-Venant equations by characteristics and finite difference methods for unsteady flow analyzing in open channel. International Journal of Hydrology Science and Technology, 6(3), 918.

[45] Ostad-Ali-Askari K, Shayannejad M, Eslamian S, et al. 2017, Deficit Irrigation: Optimization Models. Management of Drought and Water Scarcity. Handbook of Drought and Water Scarcity, Taylor \& Francis Publisher, USA. Vol. 3.1 ${ }^{\text {th }}$ Edition, pp: 373-389.

[46] Eskandari S, Hoodaji M, Tahmourespour A, Abdollahi A, Mohammadian-Baghi T, Eslamian S, Ostad-Ali-Askari K. 2017, Bioremediation of Polycyclic Aromatic Hydrocarbons by Bacillus Licheniformis ATHE9 and Bacillus Mojavensis ATHE13 as Newly Strains Isolated from OilContaminated Soil. Journal of Geography, Environment and Earth Science International, 11(2): $1-11$.

[47] Raeisi Vanani H, Shayannejad M, Soltani Tudeshki A.R, Ostad-Ali-Askari K, Eslamian S, et al. 2017, Development of a new method for determination of infiltration coefficients in furrow irrigation with natural non-uniformity of slope. Sustain. Water Resour. Manag., 3(2): 163-169.

[48] Shojaei N, Shafaei-Bejestan M, Eslamian S, Marani-Barzani M, P. Singh V, Kazemi M, OstadAli-Askari K. 2017, Assessment of Drainage Slope on the Manning Coarseness Coefficient in Mountain Area. International Journal of Constructive Research in Civil Engineering (IJCRCE), 3(1): 33-40. 
[49] Bahmanpour H, Awhadi S, Enjili J, Hosseini S.M, Raeisi Vanani H, Eslamian S, Ostad-AliAskari K. 2017, Optimizing Absorbent Bentonite and Evaluation of Contaminants Removal from Petrochemical Industries Wastewater. International Journal of Constructive Research in Civil Engineering (IJCRCE), 3(2): 34-42.

[50] Shayannejad M, Eslamian S, Gandomkar A, Marani-Barzani M, Amoushahi-Khouzani M, Majidifar Z, Rajaei-Rizi F, Kazemi M, P. Singh V, Dehghan SH, Shirvani-Dastgerdi H.R, Norouzi H, Ostad-Ali-Askari K. 2017, A Proper Way to Install Trapezoidal Flumes for Measurements in Furrow Irrigation Systems. International Journal of Research Studies in Agricultural Sciences (IJRSAS), 3(7): 1-5.

[51] Dehghan Sh, Kamaneh S.A.A., Eslamian S, Gandomkar A, Marani-Barzani M, AmoushahiKhouzani M, Singh V.P., Ostad-Ali-Askari K. 2017, Changes in Temperature and Precipitation with the Analysis of Geomorphic Basin Chaos in Shiraz, Iran. International Journal of Constructive Research in Civil Engineering (IJCRCE), 3(2): 50-57.

[52] Ostad-Ali-Askari K, Shayannejad M. 2016, FLOOD ROUTING IN RIVERS BY MUSKINGUM'S METHOD WITH NEW ADJUSTED COEFFICIENTS. International Water Technology Journal, IWTJ, 6(3): 189-194.

[53] Ostad-Ali-Askari K, Shayannejad M, Ghorbanizadeh-Kharazi H. 2017, Artificial Neural Network for Modeling Nitrate Pollution of Groundwater in Marginal Area of Zayandeh-rood River, Isfahan, Iran. KSCE Journal of Civil Engineering, 21(1):134-140. Korean Society of Civil Engineers. DOI 10.1007/s12205-016-0572-8.

[54] Raeisi-Vanani H, Soltani-Toudeshki A.R, Shayannejad M, Ostad-Ali-Askari K, Ramesh A, Singh V.P., Eslamian S. 2017, Wastewater and Magnetized Wastewater Effects on Soil Erosion in Furrow Irrigation. International Journal of Research Studies in Agricultural Sciences (IJRSAS), 3(8): 1-14. http://dx.doi.org/10.20431/2454-6224.0308001.

[55] Eslamian, S. S. and N. Lavaei, 2009, Modelling Nitrate Pollution of Groundwater using Artificial Neural Network and Genetic Algorithm in an Arid Zone, International Journal of Water, Special Issue on Groundwater and Surface Water Interaction (GSWI), Vol. 5, No. 2, 194203.

[56] Ebrahimizadeh, M. A., Amiri, M. J., Eslamian, S. S., Abedi-Koupai, J. and M. Khozaei, 2009, The Effects of Different Water Qualities and Irrigation Methods on Soil Chemical Properties, Research Journal of Environmental Sciences, Vol. 3, No. 4, 497-503.

[57] Mukherjee, S., Yadav, K., Eslamian, S., 2017, Soil Contaminations in Arid and Semiarid Land, Ch. 29 in Handbook of Drought and Water Scarcity, Vol. 2: Environmental Impacts and Analysis of Drought and Water Scarcity, Ed. by Eslamian S. and Eslamian F., Francis and Taylor, CRC Press, USA, 547-556.

[58] Ghazavi, R., Vali, A. B. and S. S. Eslamian, 2010, Impact of flood spreading on infiltration rate and soil properties in an arid environment, Water Resources Management, Vol. 24, No. 11, 2781-2793.

[59] Ebrahimizadeh, M. A., Amiri, M. J., Eslamian, S. S., Abedi-Koupai, J. and M. Khozaei, 2009, The Effects of Different Water Qualities and Irrigation Methods on Soil Chemical Properties, Research Journal of Environmental Sciences, Vol. 3, No. 4, 497-503.

[60] Abedi-Koupai J., Eslamian S. S. and J. Asad Kazemi, 2008, Enhancing the available Water Content in Unsaturated Soil Zone using Hydrogel, to Improve Plant Growth Indices, Ecohydrology and Hydrobiology, Vol. 8, No. 1, 3-11.

[61] Salahshur, Sh., Bazrkar, H. and Eslamian, S.S., 2013, Petroleum pollution as a predicament to soil and water resources, The 2nd international conference on water energy and environment, 2124 September, Turkey.

[62] Amini Nezhad, S. M. and S. S. Eslamian, 2012, Toward a more Holistic Perspective of Soil Erosion, Dust Haze Events and Interaction between Aeolian and Fluvial Transport Processes, the 1st International Congress on Dust Haze and Combating its Adverse Effects, Ahvaz, Iran.

[63] Mirabbasi, R. and S. S. Eslamian, 2010, Delineation of Groundwater Quality Concerning Applicability of Pressure Irrigation System in Sirjan Watershed, Iran, International Conference on Management of Soil and Groundwater Salinization in Arid Regions, Sultan Qaboos University, Muscat, Oman. 
[64] Zareian, M. J., Eslamian, S. S., and Safavi, H. R. 2016, Investigating the Effects of Sustainability of Climate Change on the Agriculture Water Consumption in the Zayandeh-Rud River Basin, Water and Soil Sci., Vol. 20, No. 75, 113-128.

[65] Malekian, R., Abedi-Koupai, J. and S. S. Eslamian, 2014, Estimating Parameters of LEACHN in Zeolite-Amended Soil and Unamended-Soil Conditions, JWSS-Isfahan University of Technology, Vol. 18, No. 68, 197-210.

[66] Mirabbasi Najafabadi, R., Fakheri-Fard, A., Dinpashoh, Y. and Eslamian, S. S., 2013, Longterm Drought Monitoring of Urmia Using Joint Deficit Index (JDI), Journal of Water and Soil Knowledge, Vol. 23, No. 4, 87-103.

[67] Abedi-Koupai, J., Ghaheri, E., Eslamian, S.S. and Hosseini, H., 2013, Investigation the Kinetic Models of Biological Removal of Petroleum Contaminated Soil around Oil Pipeline Using Ryegrass, Water and Wastewater, Vol. 89, No. 1, 62-68.

[68] Abedi-Koupai , J., Eslamian, S. S., Gohari , S. A., and R. Khodadadi, 2011, Evaluation of Mechanical Properties of Water Conveyance Concrete Canals Incorporating Nano Pozzolan of Wheat Ash Sheath, The Journal of Science and Technology of Agriculture and Natural Resources, Water and Soil Science, Vol. 14, No. 54, 39-52.

[69] Akhavan, S., Abedi-Koupai, J., Mousavi, S. F., Abbaspour, K., Afyuni, M. and S. S. Eslamian, 2010, Estimation of Blue Water and Green Water Using SWAT Model in Hamadan-Bahar Watershed, The Journal of Science and Technology of Agriculture and Natural Resources, Water and Soil Science, Vol. 14, No. 53, 9-23.

[70] Eslamian, S. S. and A. Ghodarzi, 2007, Evaluation of flood spreading system and artificial recharge of Bagh-sorkh aquifer in Shahreza on groundwater quality and quantity, Soil and Water Journal, Vol. 21, No. 1, 145-153.

[71] Eslamian S., Hjjarzadeh B., Gohari A., M.J. Zareian, 2006, The Effect of Reused Water in the Cultivated Soil of Najaf-Abad City, The 10th Conference of Soil Science. University Tehran, Iran.

[72] Osroosh, Y., Mostafazadeh, B. and S. Eslamian, 2004, Design, manufacturing and calibration of automatic on and off water delivery system for surge flow irrigation. Proceedings of the First National Conference on Watershed and Soil \& Water Management, Kerman, Iran.

[73] Behzadi-Nasab, M., Eslamian S. S. and Y., 2002, Influence of water pumping on groundwater surface level in west region of Dez irrigation network, 1st Student Conference on Soil and Water Resources, Urumia University, Iran.

Citation: Hamid Raeisi Vanani, et al." A Simple Method for Land Grading Computations and its Comparison with Genetic Algorithm (GA) Method", International Journal of Research Studies in Agricultural Sciences (IJRSAS), vol. 3, no. 8, p. 13, 2017, http://dx.doi.org /10.20431 /2454-6224.0308004.

Copyright: (C) 2017 Authors. This is an open-access article distributed under the terms of the Creative Commons Attribution License, which permits unrestricted use, distribution, and reproduction in any medium, provided the original author and source are credited. 